\title{
IMPLEMENTATION OF GUIDED INQUIRY LEARNING MODEL TO EXERCISE STUDENTS CRITICAL THINKING SKILLS ON REACTION RATE MATERIAL
}

\author{
R. Ayu Sofi'ah Wilatika ${ }^{1}$ and Bertha Yonata ${ }^{2 *}$ \\ Chemistry Education Study Program, Faculty of Mathematics and Natural Sciences, Universitas Negeri Surabaya, \\ Surabaya, Indonesia \\ *Email: berthayonata@unesa.ac.id
}

Accepted: January 08, 2022. Approved: January 14, 2022. Published: January 15, 2022

\begin{abstract}
The goal of this study is to explain how the inquiry-based learning model is put into practice, student activities during learning, critical thinking skills learning results, and learning outcomes in knowledge. Students in class XI-IPA 5 SMA Negeri 1 Menganti Gresik Jawa Timur were the study's subjects. This type of study uses a preexperimental design with a One-Group Pretest-Posttest Design. Data analysis using percentage techniques, normality tests, N-Gain, and paired sample t-test showed a sig value of 0.000 . (1) The quality of the guided inquiry learning model implementation was $93 \%$ in Phase $1.94 \%$ in Phase $2.93 \%$ in Phase $3.91 \%$ in Phase $4.88 \%$ in Phase 5, and 90\% in Phase 6, according to the findings of this study; (2) Relevant student activities dominate irrelevant student activities; (3) The average value of $\mathrm{N}$-gain on the interpretation indicator of 0.80 (high), inference of 0.84 (high), analysis of 0.74 (high), and explanation of 0.76 (high) indicates that students' critical thinking skills have improved; (4) In the area of knowledge, learning outcomes of students achieved classical completeness of $91.43 \%$, which exceeded the Minimum Completeness Criteria.
\end{abstract}

Keywords: Guided Inquiry, Critical Thinking Skills, Reaction Rate.

\section{INTRODUCTION}

Science and technology are quickly evolving in many aspects of society in the $21^{\text {st }}$ century, particularly in information and communication technology. Based on this statement, it is clear that education will face more complex issues, one of which is the requirement that education develops human resources who are fully capable of meeting all life's challenges [1].

All existing sciences can be used to develop $21^{\text {st }}$-century skills, one of the most important sciences in the world is divided into four categories: science, linguistics, social science, and mathematics. Chemistry is one of the subjects that belong to the scientific category, and it is a science that plays an important role in education.

Chemistry subjects are always related to problems and problem solving systematically. Learning chemistry in schools is more than just acquiring facts, concepts, or principles is an example of knowledge and discovery processes [2]. Skills in thinking and reasoning processes are included in chemistry learning. Besides, chemistry requires proof of concept through an experiment [3]. Chemistry is learning that involves the concept of calculation and conducting experiments [4].

Chemical materials based on laboratory activities are designed to teach hands-on and mind-on abilities. Minds engaged in various activities, one of which is the development of thinking abilities. According to the basic competencies that students must obtain in the sub-material elements that affect reaction rates, one of the relevant chemical materials to develop thinking skills is the reaction rate material. Basic competencies KD 3.6: Using collision theory to explain factors impacting reaction rates. $\mathrm{KD} 4.6$ :
Presenting the findings of a search for information on arranging and storing items such that uncontrollable physical and chemical changes do not occur. KD 3.7: Using experimental data to determine the reaction order and reaction rate constants. KD 4.7: Planning, performing, completing, and presenting the findings of experiments on factors that affect reaction rate and reaction order [5].

According to the analysis of the basic competencies KD, students should comprehend theoretical concepts, observe, ask questions, design, collect data, analyze, conclude, and present experimental data regarding the elements that affect reaction rates in the reaction rate material. Factors that affect the reaction rate are materials whose characteristics need to be proven through experiments by asking students to research, analyze, and conclude experimental results [6]. The material factors that affect the reaction rate have characteristics that require proof so that through experimentation, students can find the concept for themselves [7]. Experiments are used to carry out laboratory tasks. Data from student experiments will be analyzed to develop their notions regarding the factors that determine reaction speeds. As a result, it is vital to provide opportunities for pupils to construct their knowledge through thinking skills while learning the reaction rate material. Thinking critically is one of the most crucial cognitive abilities that children should develop [8].

Students were given critical thinking skills since they can teach them to think deeply to solve a problem. According to Facione [9], critical thinking skills are comprised of six indicators: interpretation, analysis, inference, evaluation, explanation, and selfregulation. Only four indicators were employed to 
develop critical thinking abilities in this study: interpretation, inference, analysis, and explanation.

Critical thinking is a talent for people to live a successful life and for communities to deal with present and future issues [10]. Critical thinking abilities are required to live, work, and function effectively in all facets of life [11]. Critical thinking is a line of thinking that involves reflection, reasoning, and problem-solving judgments [12]. Critical thinking is a comprehensive, logical, and decision-oriented pattern of thinking about a certain thing that needs to be done [13].

Students can use critical thinking to improve their knowledge of the studied content. Concepts learned through critical thinking will be remembered for longer because students actively participate in learning to find concepts independently [14]. Integrating critical thinking abilities with the material being taught is one method to accomplish this. It demonstrates that a shift from teacher-centered to student-centered learning is required to develop critical thinking abilities.

The learning model of guided inquiry is a chemical learning method that is ideal for the reaction rate material and is student-centered. Guided inquiry is a learner-centered learning model where students will discover a concept, event, or principle through direct experience from a lesson because the teacher only functions as a supporter and facilitator [15]. Inquiry-based learning often focuses more on questions and ideas that can stimulate students to explore and create ways of communicating what they have learned [16]. The guided inquiry model can encourage students to actively investigate their knowledge, allowing them to become self-sufficient, engaged, and capable of solving challenges based on knowledge and awareness [17]. According to Arends [18], an inquiry is a learning strategy designed to educate students on thinking critically. Students construct their knowledge (discovery) about a concept via guided inquiry, another form of learning methodology. It is hoped that their learning will be more meaningful due to their experiences during the learning process with instructor direction and that the things they have acquired will be retained in long-term memory and will be easy to recall. The stages of inquiry-based learning are as follows: 1. Drawing attention to the problem and explaining the inquiry learning process; 2 . presenting inquiry problems; 3 . establishing hypotheses; 4 . gathering data; 5 . formulating explanations and conclusions; 6 . reflecting on the problem and thinking skills used during the learning process [18].

The guided inquiry learning model has several stages that correspond to critical thinking abilities. Forming hypotheses, gathering data, articulating conclusions, and commenting on difficulties are phases that can help students learn to think critically through an experiment, especially practicum, to find concepts on their own. According to Herjinda \& Muchlis [19], the implementation of inquiry learning demonstrates the participation of students' critical thinking skills at each stage of learning syntax. It may be noticed instantly at every phase of inquiry learning, especially in the four essential skills of thinking identified by Facione [9]. Data interpretation might be made during the data collection orientation step. Students explain things at the orientation step while they're formulating hypotheses and when they're formulating conclusions. When creating and testing hypotheses, analysis is used. The final part of the investigation, developing conclusions, requires inference abilities.

The results of the pre-research, which took place on September $24^{\text {th }}, 2021$, at SMA Negeri 1 Menganti Gresik East Java Indonesia on 31 students in class XII IPA 2, were based on number intervals on a scale of $0-100$ on the interpretation indicator (044.4), inference (0-16.67), analysis (0-31.58), and explanation indicator (0-16.67). Based on the preliminary research findings, it can be stated that students aren't used to dealing with problems, and thus their critical thinking skills are still missing.

\section{RESEARCH METHOD}

The research technique used was preexperimental design, Using a population of 35 students as a sample in class XI IPA 5 at SMA Negeri 1 Menganti Gresik Jawa Timur in the academic year $2021 / 2022$. For learning outcomes in the realm of knowledge and skills, this study employed a One Group Pretest-Posttest Design, as follows:

\section{$\mathrm{O}_{1} \mathrm{X} \mathrm{O}_{2}$}

Information:

$\mathrm{O}_{1}=$ Pretest

$\mathrm{X}=$ Treatment

$\mathrm{O}_{2}=$ Posttest

The learning tools used in this study consist of Syllabus, Plan for Implementation of Learning (RPP), and Student Activity Sheets (LKPD). The instrument used in this study was an observation sheet on the implementation of the learning model, an observation sheet for student activities, a practice sheet for critical thinking skills, and a test sheet for assessing learning outcomes in the sphere of knowledge.

Three observers watched the learning model's implementation using an observation sheet on the guided inquiry learning model's implementation. The following formula is used to compute the percentage of implementation quality:

$$
\% \text { implementation }=\frac{\text { score obtained }}{\text { maximum score }} \times 100 \%
$$

The calculation results are translated into the criteria in Table 1. 
Table 1. Assessment Criteria for the Implementation of the Learning Model [20]

\begin{tabular}{cc}
\hline Percentage of & Criteria \\
\hline $0-20 \%$ & Not very good \\
$21-40 \%$ & Not good \\
$41-60 \%$ & Fairly good \\
$61-80 \%$ & Good \\
$81-100 \%$ & Very good \\
\hline
\end{tabular}

If an action has a score of $\geq 61 \%$ or falls into the good or very good categories, it is considered well done.

Observers recorded their observations on class and group activities on activity observation sheets. The following equation is used to calculate the percentage of activity:

Score $=\frac{\sum \text { the frequency of activity that appears }}{\sum \text { overall activity frequency }} \times 100 \%$
If the relevant activity dominates the irrelevant activity, student activity is good. After applying the guided inquiry learning model, the outcomes of the pretest and posttest show that critical thinking skills have improved. The following formula is used to calculate learning outcomes for critical thinking skills:

$$
\text { Critical thinking skills }=\frac{\sum \text { score obtained }}{\sum \text { maximum score }} \times 100
$$

Completeness of learning results in the area of critical thinking skills for individuals is complete if students have achieved a score of $\geq 75$ according to the KKM at SMA Negeri 1 Menganti Gresik Jawa Timur.

Furthermore, the data obtained was tested for normality. Suppose the number of samples is more than 50. In that case, the normality test used is Kolmogorov-Smirnov, while if the sample is less than 50 , then the spahiro-wilk test is used [21] so as to determine the improvement in critical thinking abilities has been estimated through analysis using the $\mathrm{N}$-Gain score, the following calculation formula is used:

$$
\mathrm{N} \text {-Gain score }=\frac{\text { posttest score }- \text { pretest score }}{\text { maximum score }- \text { pretest score }}
$$

The results $\mathrm{N}$-Gain obtained are then interpreted into the criteria in table 2.

Table 2. Score N-Gain Criteria [22]

\begin{tabular}{cc}
\hline Result & Category \\
\hline $\mathrm{G} \geq 0,7$ & High \\
$0,3 \geq \mathrm{G}<0,7$ & Medium \\
$\mathrm{G}<0,3$ & Low \\
\hline
\end{tabular}

Then, using a paired sample t-test, the pretest and posttest data were compared to see if there were any differences in the findings of students' critical thinking skills in the pretest and posttest after being treated with a guided inquiry learning model.

Test Results the realm of knowledge is known through the pretest and posttest results. The following formula is used to estimate the score of learning outcomes in the area of knowledge:

$$
\text { Score }=\frac{\text { Litems answered correctly }}{\sum^{\text {items of questions }}} \times 100 \%
$$

In the sphere of knowledge, mastery of learning outcomes individually is said to be complete if it reaches a score of $\geq 75$, according to the KKM in SMA Negeri 1 Menganti. While the following calculation procedure is used to determine classical completeness:

Classical completeness $=\sum$ students complete

$$
\text { Lall students } x 100 \%
$$

Learning outcomes in the sphere of knowledge of students in a class are classically complete if $75 \%$ of all students receive a score of $\geq 75$.

\section{RESULT AND DISCUSSION}

SMA Negeri 1 Menganti Gresik Jawa Timur was the site of this study with the target of class XI IPA 5 on October 5-15, 2021. The researcher acted as a teacher who trained critical thinking skills with a guided inquiry learning model for two meetings. The research data obtained are the implementation of the learning model, student activities during learning, learning outcomes in skills and knowledge. The following is a description of each research data:

\section{The Learning Model's Implementation}

The learning model's implementation was observed to identify how the guided inquiry learning model's syntax was implemented in the practice of critical thinking skills. Three observers observed the learning model's implementation using an observation sheet instrument for learning model's implementation. Learning is done on the sub material of factors that influence reaction time. Figure 1 shows the results of observations of the guided inquiry learning model being implemented.

Figure 1 illustrates the average quality of guided inquiry learning model implementation has increased during two meetings. Each meeting consists of three main activities: introduction, core, and closing.

The guided inquiry learning model's syntax is as follows: Phase 1. Focusing attention and explaining the inquiry learning process, Phase 2. Presenting inquiry problems, Phase 3 and formulating hypotheses, Phase 4. collecting data, Phase 5. Formulating findings and explanations, Phase 6 Reflect on the problems and thought utilized procedures during the learning process [18]. The research completed has obtained an implementation of average quality at Meeting I for Phase 1 of $96 \%$, Phase 2 of $94 \%$, Phase 3 of $96 \%$, Phase 4 of $92 \%$, Phase 5 of $92 \%$, and Phase 6 of $93 \%$. Phase 1 had a $90 \%$ 
approval rating in the second meeting, Phase 2 had a $94 \%$ approval rating, Phase 3 had a $90 \%$ approval rating, Phase 4 had a $90 \%$ approval rating, Phase 5 had an $83 \%$ approval rating, and Phase 6 had an $87 \%$ approval rating.

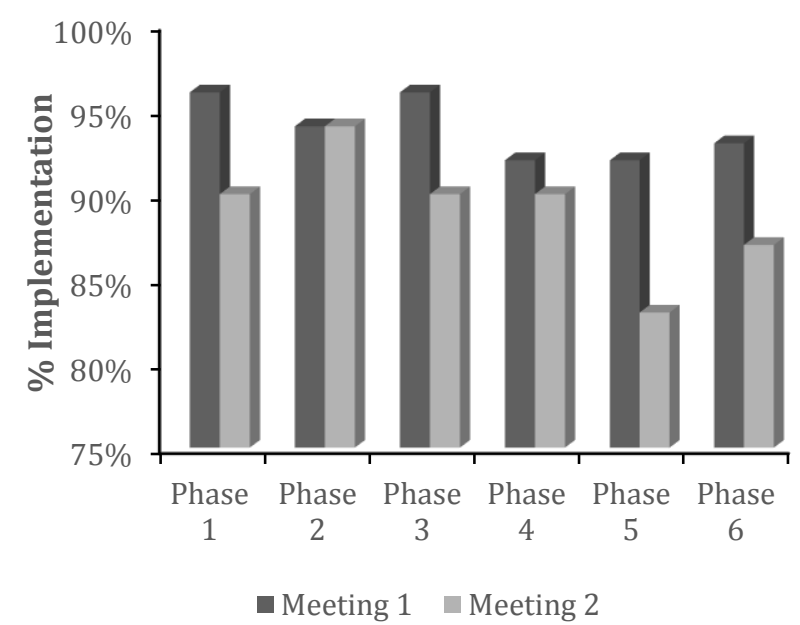

Figure 1. Implementation of the Guided Inquiry Learning Model in Percentage

Based on the research data in Figure 1, it is found that the quality of the implementation of the guided inquiry learning model has an average of $\geq 61 \%$ with very good criteria. It proves that learning with the guided inquiry model can be carried out very well in practicing critical thinking skills. Previous research shows consistent results that the guided inquiry learning model can train critical thinking skills on the reaction rate material is said to be carried out in the very good category. The learning model implementation percentage was obtained at the first meeting of $91.96 \%$ and the second meeting of $98.21 \%$ [23].

\section{Students Activities}

Three observers watched the students' activities using activity sheets. Observations of student activities during the learning process are carried out to see what activities students engage in during the learning process so that the process of students practicing critical thinking abilities may be shown.

The students' observed behavior has been adapted to the critical thinking skills taught. The teacher provides verbal guidance and written guidance when working on the worksheet. Overall, the results of relevant and irrelevant activities are presented in Figure 2.

Figure 2 shows students' activity data from the first meeting to the second meeting. The data in Figure 2 shows that relevant activities are greater than irrelevant activities. It proves that learning with the guided inquiry model effectively trains students' critical thinking skills.

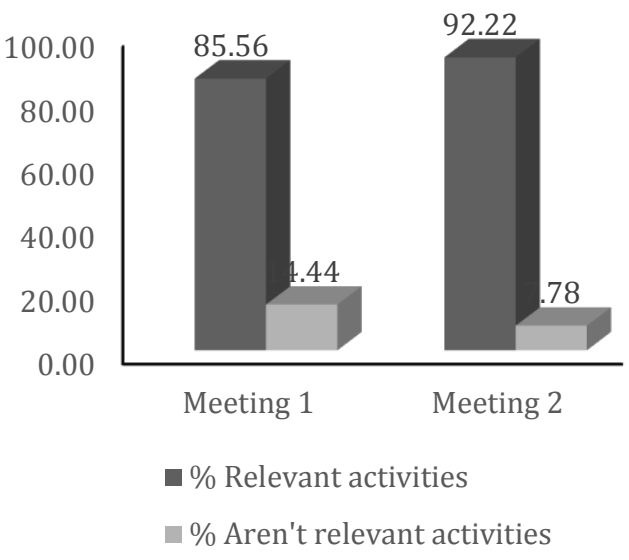

Figure 2. Percentage of Student Activity

\section{Critical Thinking Skills Areas of Learning Outcomes}

A guided inquiry learning model is used to teach critical thinking abilities. Four indicators, namely interpretation, inference, analysis, and explanation, were taught in this study. Before treatment, pupils are given a question sheet pretest to determine what skills they already have. Additionally, the students were treated in two meetings using the guided inquiry learning model. After the second meeting, students were given a posttest to determine whether they had improved their critical thinking skills. Figure 3 shows the outcomes of the scores for the pretest and posttest.

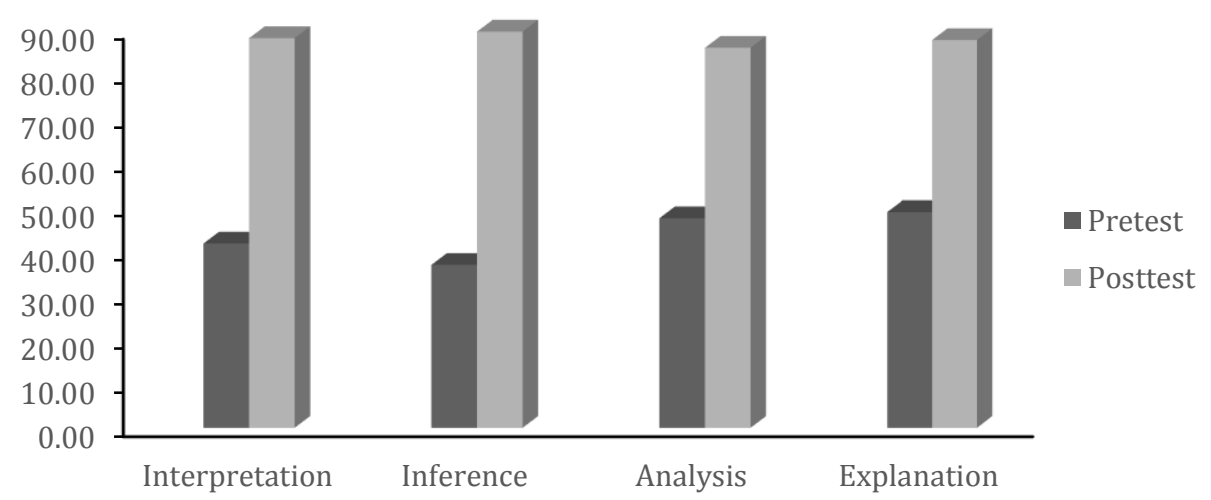

Figure 3. The average value of Critical Thinking Skills during the pretest and posttest 
Figure 3 illustrates that students' critical thinking scores increase after being trained. The results posttest obtained an average score on the interpretation indicator of $88.28 \%$, inference of $89.76 \%$, analysis of $86.11 \%$, and explanation of $87.85 \%$.

The pretest and posttest values obtained were then tested for normality first. If the number of samples is more than 50 , then the normality test used is Kolmogorov-Smirnov, while if the sample is less than 50, the spahiro-wilk test is used [21]. Table 3 summarizes the findings of the normality test.

Table 3. The normality test results on the pretest and posttest values

\section{Tests of Normality}

\begin{tabular}{lrrrrrr}
\hline & \multicolumn{3}{c}{ Kolmogorov- $^{\text {Smirnova }}{ }^{\mathrm{a}}$} & \multicolumn{3}{c}{ Shapiro-Wilk } \\
& Statistic & df & Sig. & Statistic & df & Sig. \\
\hline PRETEST & .136 & 35 & .101 & .951 & 35 & .125 \\
& .125 & 35 & .187 & .957 & 35 & .180 \\
\hline
\end{tabular}

The normality test results on the pretest score are seen in Table 3 showed sig 0.125 , and the posttest score showed sig 0.180 . These results indicate that the pretest and posttest scores have sig $>0.05$, so the research data is normally distributed.

Furthermore, the increase in critical thinking skills can be calculated through the formula N-Gain score. The study's findings of the calculation of the NGain score obtained are presented in Table 4 :
Table 4. The N-Gain results of Critical Thinking Skills

\begin{tabular}{ccccc}
\hline $\begin{array}{c}\text { Indicators of } \\
\text { critical } \\
\text { thinking } \\
\text { skills }\end{array}$ & Pretest & Posttest & N-Gain & Criteria \\
\hline Interpretation & 41.84 & 88.28 & 0.80 & High \\
Inference & 36.98 & 89.76 & 0.84 & High \\
Analysis & 47.57 & 86.11 & 0.74 & High \\
Explanation & 48.96 & 87.85 & 0.76 & High \\
\hline
\end{tabular}

The data in Table 4 demonstrates that the $\mathrm{N}$-gain value on the interpretation indicator is 0.80 (high), the inference is 0.84 (high), the analysis is 0.74 (high), and the explanation is 0.76 (high). The learning outcomes of individual critical thinking skills from 35 students have been completed because the score achieved is $\geq 75$ by the KKM for chemistry subjects at SMA Negeri 1 Menganti Gresik Jawa Timur.

The guided inquiry learning model is proven to enhance student's critical thinking skills so that all students complete the specified KKM. It is consistent with past findings, which showed that critical thinking skills were successfully improved with the guided inquiry learning model with an average $\mathrm{N}$-gain value of $0.73-0.90$ in the high category [24].

The data was then analyzed using a paired sample t-test to see if there had been any changes in students' critical thinking skills between the pretest and posttest after being treated with a guided inquiry learning model. Table 5 displays the results of the Paired sample t-test.

Table 5. The paired sample t-results test's

Paired Samples Test

Paired Differences

95\% Confidence

Interval of the

Std.

Std. Error

Difference

\begin{tabular}{|c|c|c|c|c|c|c|c|c|c|}
\hline & & Mean & Deviation & Mean & Lower & Upper & & & \\
\hline Pair1 & $\begin{array}{l}\text { PRETEST - } \\
\text { POSTTEST }\end{array}$ & -47.41229 & 3.80716 & .64353 & -48.72009 & -46.10448 & -73.676 & 34 & .000 \\
\hline
\end{tabular}

Based on the data in table 5 , the value of sig (2-tailed) is 0.000 , implying that the value is $<0.05$. The guided inquiry learning model causes a considerable change between the pretest and posttest scores.

\section{Learning Outcomes Area of Knowledge}

Students' conceptual knowledge refers to their understanding of what has been taught. The knowledge domain is known through the pretest and posttest question sheets, which contain 15 multiple choice questions in terms of learning outcomes. Questions for the pretest are given during the first meeting before learning begins, and questions for the posttest are presented at the second meeting after learning has begun. Figure 4 shows the results of the knowledge domain.

Based on Figure 4, the results of the pretest were 32 of 35 students who did not complete, while the posttest results showed that there were 32 of 35 who completed with a score exceeding the Minimum Completeness Criteria. There is an increase in students who complete the posttest and classically completeness in the realm of knowledge, which is $91.43 \%$. It means that $91.43 \%$ of students have completed a score exceeding the Minimum 
Completeness Criteria. Therefore, to improve critical thinking skills, using the guided inquiry learning model positively influences students' conceptual knowledge. These results are in tune with previous studies showing that the guided inquiry learning model for learning outcomes realm of knowledge has reached the minimum completeness criteria KKM [25].

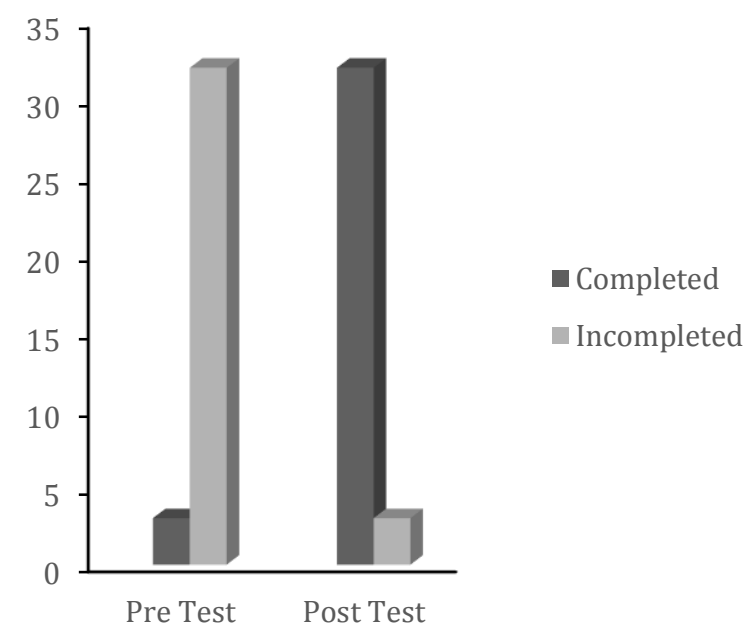

Figure 4. The outcomes of the knowledge domain's Pretest and Posttest

\section{CONCLUSION}

Based on research data, guided inquiry learning can be carried out very well in practicing critical thinking skills so that relevant student activities are more significant than irrelevant activities. In addition, students experienced an increase in critical thinking skills as evidenced by the $\mathrm{N}$-gain average value, which was in the high category. Then the learning outcomes of the knowledge domain of students obtain classical completeness that has exceeded the Minimum Completeness Criteria. It was concluded that the application of the guided inquiry learning model had a good effect on students' knowledge.

\section{REFERENCES}

[1] Yuliati, Y. (2017). Literasi Sains dalam Pembelajaran IPA. Jurnal Cakrawala Pendas Vol. 3 No.2, 22.

[2] Andriani, D. W., \& Yonata, B. (2018). Melatihkan High Order Thinking Skills Peserta Didik Melalui Implementasi Model Pembelajaran Inkuiri Pada Materi Kesetimbangan Kimia. Unesa Journal of Chemical Education Vol. 7 No. 3, 334.

[3] Nurkholik, M., \& Yonata, B. (2020). Implementasi Model Pembelajaran Inkuiri Untuk Melatihkan High Order Thinking Skills Peserta Didik Pada Materi Laju Reaksi Kelas XI IPA MAN 2 Gresik. Unesa Journal of Chemical Education Vol. 9 No. 1, 159.
[4] Hidayati, N., \& Yonata, B. (2019). Penerapan Model Pembelajaran Inkuiri Terbimbing Untuk Melatihkan Keterampilan Proses Sains Peserta Didik Pada Materi Kesetimbangan Kimia Kelas XI SMAN Ngoro Jombang. Unesa Journal of Chemical Education Vol.8, No. 2, 149.

[5] Permendikbud. (2016). Permendikbud Nomor 24 Tahun 2016 Tentang Kompetensi Inti dan Kompetensi Dasar Pelajaran Kurikulum 2013. Jakarta: Mendikbud.

[6] Ilaah, Y. F., \& Yonata, B. (2015). Keterampilan Berpikir Kritis Siswa SMA Kemala Bhayangkari 1 Surabaya Pada Materi Laju Reaksi Melalui Penerapan Model Pembelajaran Inkuiri. UNESA Journal of Chemical Education Vol. 1, No. 1, 79.

[7] Mayasari, P. I., \& Yonata, B. (2019). Pengembangan Lembar Kerja Siswa Berbasis Inkuiri Terbimbing Untuk Melatihkan Keterampilan Berpikir Kreatif Pada Materi Laju Reaksi. Unesa Journal ofChemical Education Vol. 8 No. 2.

[8] Jamaluddin, Jufri, A. W., Muhlis, \& Bahtiar, I. (2020). Pengembangan Instrumen Keterampilan Berpikir Kritis Pada Pembelajaran IPA. J. Pijar MIPA, Vol. 15 No.1, 14.

[9] Facione, P. A. (2011). Critical Thinking: What It Is and Why It Counts. In Insight assessment (Issue ISBN 13: 978-1-891557-07-1.). California Academic Press.

[10] Nugraha, A. J., Suyitno, H., \& Susilaningsih, E. (2017). Analisis Kemampuan Berpikir Kritis Ditinjau dari Keterampilan Proses Sains dan Motivasi Belajar melalui Model PBL. Journal of Primary Education, 37.

[11] Samura, A. O. (2019). Kemampuan Berpikir Kritis dan Kreatif Matematis Melalui Pembelajaran Berbasis Masalah. Journal of Mathematics Education and Science Vol. 5, No. 1,, 20-21.

[12] Rahmadhani, P., Novita, D., \& Yonata, B. (2018). Implementation Of Guided Inquiry Learning Models With Nested Method To Increase Critical Thinking Skill For ElevenGrade Student At SMA Negeri 1 Manyar Gresik In Reaction Rate Matter. UNESA Journal of Chemistry Education Vol. 07, No. 1, 40.

[13] Zakiyah, F., \& Yonata, B. (2021). Pengembangan LKPD Berorientasi Guided Discovery Learning dengan Internet Assisted Learning untuk Melatihkan Keterampilan Berpikir Kritis. Jurnal Inovasi Pembelajaran Kimia, 48.

[14] Depdiknas. (2009). Panduan Teknis Pembelajaran yang Mengembangkan Critical Thinking. Jakarta: Jendral Manajemen Pendidikan Dasar dan Menengah Direktorat Pembinaan Sekolah Menengah Pertama.

[15] Ayuningtiyas, F., \& Yonata, B. (2019). Implementation of Guided Inquiry Learning to Train Students Science Process Skills of 
Chemistry Equilibrium Materials. Journal of Chemistry Education Research Vol. 3, No. 1.

[16] Aini, N., \& Yonata, B. (2020). Implementasi Model Pembelajaran Inkuiri Terbimbing Pada Materi Kesetimbangan Kimia Untuk Melatihkan Keterampilan Berpikir Tingkat Tinggi. UNESA Journal of Chemical Education Vol.9, No.2.

[17] Amijaya, L. S., Ramdani, A., \& Merta, I. W. (2018). Pengaruh Model Pembelajaran Inkuiri Terbimbing Terhadap Hasil Belajar dan Kemampuan Berpikir Kritis Peserta Didik. J. Pijar MIPA, Vol. 13 No.2, 96.

[18] Arends, R. (2012). Learning to Teach Ninth Edition (B. Mejia (ed.); ninth, Vol. 7, Issue 2).

[19] Herjinda, W., \& Muchlis. (2015). Penerapan Model Pembelajaran Inkuiri Untuk Melatihkan Keterampilan Berpikir Kritis Siswa Pada Materi Pokok Asam Basa Kelas XI SMAN 2 Magetan. UNESA Journal of Chemical Education Vol. 4, No. 2, 327.

[20] Riduwan. (2015). Skala Pengukuran VariabelVariabel Penelitian. Bandung: Alfabeta.

[21] Tyastirin, E., \& Hidayati, I. (2017). Statistik Parametrik untuk Penelitian Kesehatan. Surabaya: Program Studi Arsitektur UIN Sunan Ampel.

[22] Hake, R. (1998). Interactive Engagement Versus Tadisional Methods: A Six Thousand Student Survey of Mecanics Test Dta for Introductory Physics Courses. American Journal OF Physics.

[23] Febriani, D. R., \& Ismono. (2020). Penerapan Model Pembelajaran Inkuiri Terbimbing Untuk Melatihkan Keterampilan Berpikir Kritis Pada Materi Laju Reaksi Kelas XI. UNESA Journal of Chemical Education Vol. 9, No. 2.

[24] Cahyani, N. I., \& Azizah, U. (2019). Penerapan Model Pembelajaran Inkuiri Terbimbing untuk Melatihkan Keterampilan Berpikir Kritis Pada Materi Laju Reaksi Kelas XI SMA. UNESA Journal of Chemistry Education Vol.8. No.3.

[25] Mukmainah, S. A., \& Yonata, B. (2020). Penerapan Model Pembelajaran Inkuiri Terbimbing untuk Meningkatkan Keterampilan Berpikir Kritis Peserta Didik Pada Materi Laju Reaksi di SMAN 1 Rengel. UNESA Journal of Chemistry Education Vol 9, No.1, 138. 